\title{
Contribution of chromosomal abnormalities and genes of the major histocompatibility complex to early pregnancy losses
}

\author{
I. R. Tkach ${ }^{1}$, K. O. Sosnina ${ }^{1}$, N. L. Huleyuk ${ }^{1}$, O. I. Terpylyak ${ }^{1}$, \\ D. V. Zastavna ${ }^{1}$, A. Weise ${ }^{2}$, N. Kosyakova ${ }^{2}$, T. Liehr ${ }^{2}$ \\ ${ }^{1}$ State Institution «Institute of Hereditary Pathology, NAMS of Ukraine» \\ 31a, M. Lysenko Str., Lviv, Ukraine, 79008 \\ 2 Jena University Hospital, Friedrich Schiller University, Institute of Human Genetics \\ 10, Kollegiengasse, Jena, Germany, D-07743 \\ huleyuk@yahoo.com
}

\begin{abstract}
Aim. The determination of chromosomal abnormalities in samples from early pregnancy losses and allelic polymorphism of $H L A-D R B 1$ and $D Q A 1$ genes in couples with recurrent miscarriage. Methods. Banding cytogenetic and interphase mFISH analysis, DNA extraction by salting method, PCR, agarose gel electrophoresis. Results. Cytogenetic and molecular-cytogenetic investigations of SA material identified karyotype anomalies in $32.4 \%$ of cases with prevalence of autosomal trisomy $-42.65 \%$, triploidy $-30.38 \%$ and monosomy X $-19.11 \%$. Complex analysis of frequency and distribution of allelic variants of genes $H L A$ $D R B 1$ and $H L A-D Q A 1$ allowed establishing the alleles $D R B 1 * 0301, D R B 1 * 1101-1104$ and $D Q A 1 * 0501$ to be aggressor alleles in women with recurrent pregnancy loss (RPL). The cumulative homology of allelic polymorphism of more than $50 \%$ of HLA-DRB1 and HLA-DQA1 loci between partners increases the risk of RPL by almost four times. Conclusion. The detected chromosome aneuploidies in the samples from products of conception and the changes in the major histocompatibility complex genes can cause the failure of a couples reproductive function and can lead to an early fetal loss.
\end{abstract}

Keywords: pregnancy loss, chromosome abnormalities, cytogenetics, mFISH, chromosome, HLAgenotyping.

\section{Introduction}

Approximately $15 \%$ of all clinically recognized pregnancies are spontaneously aborted. Miscarriage includes spontaneous abortions (SA) from the start to the 23-rd week of gestation $[1,2]$. The most often cited preconditions for recurrent miscarriages (RM) are the antiphospholipid syndrome in mothers, genetic abnormalities in parents or in fetuses, anatomical and endocrine factors, inherited thrombophilias and various immunological causes [3, 4]. Among the most frequent risk factors for SA are the age of the mother and the pathology of the fetus.

Pregnancy losses (PL) in 60 to $80 \%$ of the cases are associated with chromosomal abnormalities (CA) in embryos or fetuses [5-13]. Up to $95 \%$ of conceptions with $\mathrm{CA}$ are eliminated before pregnancy is diagnosed $[10,14]$. Structure and spectrum of CA in samples from PL are significantly different from the spectrum in newborns. Among lost pregnancies of the first trimester (early pregnancy losses, EPL) the highest fractions of CA constitute of trisomies - 50 $60 \%$, of which trisomy of chromosome 16 occurs in 15-20\%. Less numerous in such cases are polyploidies (20-25\%), monosomies (10-15\%) and structural anomalies (5-6\%) [10,11,13,15]. Among EPL the highest percentage of trisomies involves, in decreasing order, chromosomes $16,22,21,15,13,18[14$, 16]. Concerning monosomies, the gonosomal monosomy of the $\mathrm{X}$ chromosome is the most prevalent

(C) 2015 I. R. Tkach et al.; Published by the Institute of Molecular Biology and Genetics, NAS of Ukraine on behalf of Biopolymers and Cell. This is an Open Access article distributed under the terms of the Creative Commons Attribution License (http://creativecommons.org/licenses/by/4.0/), which permits unrestricted reuse, distribution, and reproduction in any medium, provided the original work is properly cited 
Contribution of chromosomal abnormalities and genes of the major histocompatibility complex to early pregnancy losses

one and is found in $10 \%$ of all CA cases [10,16-18]. In EPL occurring up to the 10th week of pregnancy, double and triple trisomies involving different chromosomes are often found. In most cases, autosomal double trisomies, regardless of the chromosomes involved, are lethal $[17,19]$. Polyploidies are compatible with a fetal development in humans only as triploids 69, XXX and 69, XXY [12, 20, 21].

Information about the structure of CA in $\mathrm{SA}$ is gathered on the basis of numerous cytogenetic studies of various tissues using conventional cytogenetic analysis of metaphase chromosomes. However, as fetal tissue may be retained in utero for several days or weeks after the fetal demise, the tissue may be autolyzed and unresponsive to standard chromosome analysis. With the development of new methods like molecular cytogenetics, more opportunities arise that enable the study of karyotypes in uncultured cells from SA [20]. Interphase FISH allows identifying all types of numerical abnormalities (aneuploidy and polyploidy), including mosaic forms $[18,21-$ 23]. Consequently, studying the frequency and spectrum of CA in EPL is a key part of the investigations of reproductive failure in humans.

Immunologic factors contribute to PL especially at the early stages of gestation (up to 14 weeks). In particular, $45 \%$ of cases of the EPL are accompanied by immunologic intolerance to the fetus. In such instances the immune system of the mother organism reacts to the fetus antigens as to foreign antigens and aims towards the destruction of the antigen source. The studies on misregulated interaction between the cells of the mother and the fetus are key issues for the identification of factors involved in SA.

One of the main factors involved in immune responses is the major histocompatibility complex (MHC) encoded by human leukocyte antigen (HLA) gene locus. The HLA is an extended region of the genome that spans some 4 million base pairs (bp) on the short arm of human chromosome 6 between 6 p21.31 and 6p21.32. The involvement of the HLA system in predisposition to RM has been analyzed through the identification of particular HLA genes that are linked to reproductive losses [24-26], to similarities of HLA antigens between partners [27] and to genes involved in modulation of the HLA system in the gene expression network [28].

In this study we have investigated chromosome abnormalities in a series of SA material samples and have analyzed the prevalence of $H L A-D R B 1$ and $D Q A 1$ alleles in the couples with RPL.

\section{Materials and Methods.}

Specimens from SA in the period from 4 to 14 weeks of gestation were obtained from 209 females aged 22 to 42 years. DNA for HLA analysis was extracted from peripheral blood leukocytes of 38 couples with recurrent miscarriage and 34 couples with the absence of miscarriages in anamnesis and having two or more children. All of the cases included in the present study were approved by the Ethics committee of the Institute of Hereditary Pathology NAMS of Ukraine. Informed consent for cytogenetic study and HLA-genotyping was obtained from all patients.

\section{Banding cytogenetic processing}

For SA material processing, the cells of the chorionic villi were separated from the decidual cells. We used the method of direct chromosome preparation from chorion [29] and analyzed the samples cytogenetically using G-banded cytogenetic techniques. Samples were visualized under a light microscope (Zeiss, Axioscope; Jena, Germany). A minimum of 10 metaphases were scored per sample.

\section{Interphase multicolor fluorescence in situ hybridization (mFISH) analysis}

Preliminary analysis was performed on interphase nuclei. The hybridization, post-hybridization washes and detection steps were done as described in [30]. Image acquisition was performed using an Axioplan II microscope (Carl Zeiss Jena $\mathrm{GmbH}$ ) equipped with filter sets for DAPI, FITC, TR, Cy3 and Cy5 fluorescence channels. Image analysis was done with the help of Isis DGTSa, BGR-I and DGSoSa software (MetaSystems Hard \& Software GmbH, Altlussheim, Germany). Three homemade probe sets were used as specified below:

$-\operatorname{mix} 1$ : centromeric probes for 13p11.1-q11 and 21p11.1-q11.1 (D13/21Z1, labeled in Spectrum Gre- 
en $=\mathrm{SG}), 15 \mathrm{q} 11(\mathrm{D} 15 \mathrm{Z} 3$ labeled in Texas-red $=\mathrm{TR})$, and 18p11.1-q11.1 (D18Z1 labeled in - Diethylaminocoumarin $=$ DEAC);

- mix 2: centromeric probes for 14p11.1-q11.1 and 22p11.1-q11.1 (D14/22Z1 labeled in Spectrum Gre en $=\mathrm{SG})$ and 16p11.1-q11.1 (D16Z2 labeled in TR);

- mix 3: centromeric probes for $17 \mathrm{p} 11.1-\mathrm{q} 11.1$ $(\mathrm{D} 17 \mathrm{Z1}$ labeled in SepctrumOrange $=\mathrm{SO})$ and Xp11.1-q11.1 (DXZ1 labeled in DEAC), together with a probe for Yq12 (DYZ1 labeled in SG).

All probe sets were first tested separately on human metaphase spreads prior to use in probe mixes to evaluate quality and to exclude contamination. The region specific probes were mapped cytogenetically based on the inverted DAPI banding pattern of chromosomes. At least 100 interphase nuclei per sample were analyzed.

\section{HLA analysis}

DNA was extracted from peripheral blood leukocytes using the salting-out method. The genotyping of $H L A-D R B$ and $H L A-D Q A 1$ was performed using polymerase chain reaction (PCR) in Terzik thermocycler (DNA-technology, Russian Federation (RF)) with automated regime according to the corresponding amplification program. The typing of alleles of the above mentioned genes was conducted using the reagent kits designed for genotyping via DNA amplification by PCR with sequence-specific primers: «GenPak®HLA-DRBPCR test» and «GenPak ${ }^{\circledR H L A-}$ DQA1 PCR test» (Laboratory Isogen LLC, RF). PCR products of allelic variants were detected by 3 $\%$ agarose gel electrophoresis, stained with ethidium bromide in UV-light at $302 \mathrm{~nm}$.

Statistical processing of results was conducted using Pearson criterion $\chi^{2}$. The critical level of significance for statistical criteria for all the types of analysis was defined as $p<0.05$. The association of genotypes and alleles with the risk of reproductive failure was evaluated by calculating the odds ratio (OR) with $95 \%$ confidence interval.

\section{Results and Discussion}

We performed banding and molecular cytogenetic studies on 209 chorionic villus sampling (CVS) specimens from women with sonographically diagnosed MAs or blighted ovum (from 4 to 14 weeks of gestation). Banding cytogenetic results were obtainable in 120 cases. To test the products of conception where the banding analysis was impossible due to the absence of metaphases, the mFISH analysis was performed. mFISH has been described as the current gold standard to determine the numerical chromosome aneuploidies (NCA) and polyploidies. In contrast to karyotyping, it can be used on interphase nuclei, so it can be applied on specimens from CVS. The mFISH analysis added the value to the complex investigation performed in the current study and contributed to the profiling of NCA in tissues from EPL that is of great significance for genetic counseling of the couples with RM as well as for human reproduction investigations.

The interphase mFISH with the probe panel for chromosomes 13, 14, 15, 16, 17, 18, 21, 22, $\mathrm{X}$ and $\mathrm{Y}$ was performed on 89 uncultured cell suspensions from spontaneous abortions samples. Though not all the chromosome abnormalities can be identified simply by counting specific chromosomes within a cell, the most common abnormalities of chromosome number, including trisomy 21 , trisomy 18 , trisomy 13, 47, XXY, 47, XXX, 45, X, 47, XYY, 69, XXN and $92, \mathrm{XXNN}(\mathrm{N}$ - gonosome $\mathrm{X}$ or $\mathrm{Y})$ can be reliably determined.

Among the miscarriages, the gonosomal constitution of XY prevailed (the sex ratio XY : XX was 1.2). In 68/209 cases (32.54 \%) an abnormal karyotype was detected. None of the chromosome abnormalities were identified to be gender-skewed. The specific abnormality frequencies observed by chromosome analysis and mFISH (Table 1, Fig. 1) were comparable with other large SA cytogenetic studies $[10,11,13-15]$.

Pure autosomal trisomy (42.65\%), especially of chromosomes 16 (19.11\%), $21(7.35 \%)$ and 22 (4.41\%), polyploidy (32.35\%), especially triploidy $(30.38 \%)$ and monosomy X (19.11\%), especially in pure form $(14.71 \%)$ were the most prevalent abnormalities observed (Table 1).

An application of interphase FISH enabled to identify five cases of mosaic chromosome composi- 
tion, among them - three cases of gonosomal mosaicism: monosomy X[77]/disomy X[23], monosomy X[40]/trisomy X[60], monosomy X[96]/disomy $\mathrm{X}[4])$; and two cases of autosomal mosaicism: monosomy $15[61] /$ disomy 15 [39] and monosomy 22[26]/ disomy 22[23]/trisomy 22 [51].

Another factor of EPL according to a series of reports $[27,28,30,31]$ is the homology of HLA-antigens between the partners or the presence of aggressor allele in the woman. To follow up on this information we have attempted to identify the immunological component of RM. We have selected 38 couples with RM that had a history of at least one miscarriage and karyotyped via cytogenetic and molecular-genetic methods. The control group consisted of 34 couples with normal obstetrics and genetic anamnesis having two or more healthy children. We have investigated 16 alleles of $H L A-D R B 1$ and 10 alleles of the HLA$D Q A 1$ genes, characterized the allelic polymorphisms and genotypes based on those genes and compared the data with the control group.

Compared to the control group the results showed different allele variant frequencies of the investigated genes in the couples with RPL (38 couples, 76 individuals, 152 alleles) and more specifically - in women with RPL (38 individuals, 76 alleles). We have observed an increased frequency of the $D R B 1 * 0301$ allele in the couples with RPL (12.82\% versus $5.15 \%$ in control group, Table 2) and in the women with RPL ( $14.1 \%$ versus $4.41 \%$ ). Additiionally, in the women with RM the frequency of DRBI*1101-1104 and $D Q A 1 * 0501$ was higher than in the control group (20.51\% versus $8.82 \%$ and $38.46 \%$ versus $22.06 \%$ respectively, Table 3).

Statistical analysis identified three alleles associated with RPL. Table 2 and Table 3 show a significant increase in frequency of the allele $D R B 1 * 0301$ in the couples $\left(\chi^{2}=5.422, \mathrm{p}<0.025\right)$ and in women $\left(\chi^{2}=3.935, \mathrm{p}<0.05\right)$ with RPL, and the alleles $D R B 1 * 1101-1104\left(\chi^{2}=3.879, \mathrm{p}<0.05\right), D Q A 1 * 0501$ $\left(\chi^{2}=4.584, \mathrm{p}<0.05\right)$ in women, which supports the identification of these alleles as aggressor alleles.

Odds ratio (OR) calculation shows that carrying $D R B 1 * 0301$ allele increases the RPL risk in the couples by almost three times $(\mathrm{OR}=2.79 ; \mathrm{CI}-95 \%$ : 1.14

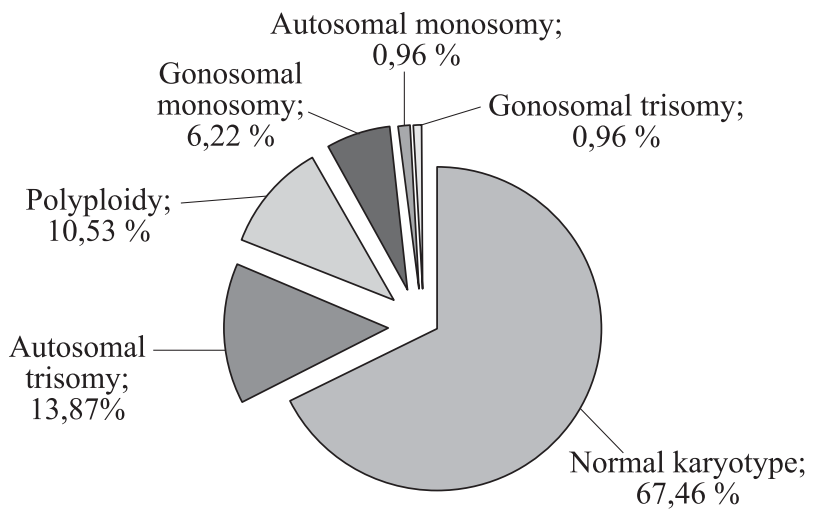

Fig. 1. Chromosomal abnormalities observed in the material from early pregnancy losses

Table 1. Spectrum and frequency of numerical chromosomal abnormalities in embryos derived from early pregnancy loss

\begin{tabular}{|l|c|c|}
\hline \multirow{2}{*}{ Karyotype } & \multicolumn{2}{c|}{ Number of cases } \\
\cline { 2 - 3 } & $\begin{array}{c}\text { absolute } \\
\text { numbers, } \mathrm{n}\end{array}$ & $\begin{array}{c}\text { percentage } \\
\text { value, \% }\end{array}$ \\
\hline monosomy X & 10 & 14.71 \\
$47, \mathrm{XXX}$ & 1 & 1.47 \\
47,XXY & 1 & 1.47 \\
trisomy 14 & 1 & 1.47 \\
trisomy 15 & 3 & 4.41 \\
trisomy 16 & 13 & 19.11 \\
trisomy 18 & 2 & 2.94 \\
trisomy 20 & 2 & 2.94 \\
trisomy 21 & 5 & 7.35 \\
trisomy 22 & 3 & 4.41 \\
Triploidy & 21 & 30.88 \\
tetraploidy & 1 & 1.47 \\
monosomy X [40] / trisomy X [60] & 1 & 1.47 \\
monosomy X [77] / disomy X [23] & 1 & 1.47 \\
monosomy X [96] / disomy X [4] & 1 & 1.47 \\
monosomy 15[61] / disomy 15 [39] & 1.47 \\
monosomy 22[26]/disomy 22[23]/ & 1.47 \\
trisomy 22[51] & 100 \\
Total & 1 & \\
\hline
\end{tabular}


I. R. Tkach, K. O. Sosnina, N. L. Huleyuk et al.

Table 2. Identified aggressor allele in couples with RPL

\begin{tabular}{|c|c|c|c|c|c|c|c|}
\hline \multirow{2}{*}{$\begin{array}{c}\text { DRB1 } \\
\text { aggressor allele }\end{array}$} & \multicolumn{2}{|c|}{$\begin{array}{c}\text { Couples with RPL (38 couples, } \\
76 \text { individuals, } 152 \text { alleles) }\end{array}$} & \multicolumn{2}{|c|}{$\begin{array}{c}\text { Control (34 couples, } \\
68 \text { individuals, 136 alleles) }\end{array}$} & \multirow{2}{*}{$\chi^{2}$} & \multirow{2}{*}{ OR(CI) } & \\
\cline { 2 - 8 } & $\mathrm{n}^{\mathrm{a}}$ & $\%^{\mathrm{b}}$ & $\mathrm{n}^{\mathrm{a}}$ & $\%^{\mathrm{b}}$ & & & \\
\hline$* 0301$ & 20 & 12.82 & 7 & 5.15 & 5.422 & $<0.025$ & $2.7922(1.1417-6.8286)$ \\
\hline
\end{tabular}

Note: a quantity of alleles in group; b frequency of alleles in group.

Table 3. Identified aggressor allele in women with RPL

\begin{tabular}{|c|c|c|c|c|c|c|c|}
\hline \multirow{2}{*}{$\begin{array}{c}H L A-I I \\
\text { aggressor alleles }\end{array}$} & \multicolumn{2}{|c|}{$\begin{array}{c}\text { Women with RPL } \\
\text { (38 women; } 76 \text { alleles) }\end{array}$} & \multicolumn{2}{|c|}{$\begin{array}{l}\text { Control group women } \\
\text { (34 women; } 68 \text { alleles) }\end{array}$} & \multirow{2}{*}{$\chi^{2}$} & \multirow{2}{*}{$\mathrm{P}$} & \multirow{2}{*}{$\mathrm{OR}(\mathrm{CI})$} \\
\hline & $\mathrm{n}^{\mathrm{a}}$ & $\%^{\mathrm{b}}$ & $\mathrm{n}^{\mathrm{a}}$ & $\%^{\mathrm{b}}$ & & & \\
\hline$D R B 1 * 0301$ & 11 & 14.10 & 3 & 4.41 & 3.935 & $<0.05$ & $3.56(0.95-13.34)$ \\
\hline$D R B 1 * 1101-1104$ & 16 & 20.51 & 6 & 8.82 & 3.879 & $<0,05$ & $2.67(0.98-7.26)$ \\
\hline
\end{tabular}

Note: a quantity of alleles in group; b frequency of alleles in group.

Table 4. Homology levels of HLA-DRB1 and HLA-DQA1 loci in investigated groups

\begin{tabular}{|c|c|c|c|c|c|c|c|}
\hline $\begin{array}{c}\text { HLA-locus quantity } \\
\text { of homologous alleles } \\
(\% \text { homology) }\end{array}$ & \multicolumn{2}{|c|}{$\begin{array}{c}\text { Couples with RPL } \\
(38 \text { couples })\end{array}$} & \multicolumn{2}{|c|}{$\begin{array}{c}\text { Control group } \\
(34 \text { couples })\end{array}$} & \multirow{2}{*}{$\chi^{2}$} & P & \\
\hline DRB1/DQA1 & $\mathrm{n}$ & $\%$ & $\mathrm{n}$ & $\%$ & & & \\
\hline $0-1(0-25 \%)$ & 22 & 57.90 & 28 & 82.35 & 5.665 & $<0.02$ & $0.28(0.094-0.821)$ \\
$2-4(50-100 \%)$ & 16 & 42.10 & 6 & 17.65 & & $3.60(1.22-10.68)$ \\
\hline
\end{tabular}

Table 5. SA material karyotype results and the level of homology of HLA-DRB1 and HLA-DQA1 loci in couples with RPL

\begin{tabular}{|c|c|c|c|c|c|c|}
\hline \multirow{3}{*}{$\begin{array}{c}\text { Allelic } D R B 1 \\
\text { and } D Q A 1 \text { homology }\end{array}$} & \multirow{3}{*}{$\begin{array}{c}\text { Couples with RPL } \\
\text { (38 couples) } \\
\text { absolute numbers, } \\
\mathrm{n}\end{array}$} & \multicolumn{5}{|c|}{ Material of pregnancy losses (40 cases) } \\
\hline & & \multirow{2}{*}{$\begin{array}{c}\text { number of cases } \\
\begin{array}{c}\text { absolute numbers, } \\
\text { n }\end{array}\end{array}$} & \multicolumn{2}{|c|}{ normal karyotype } & \multicolumn{2}{|c|}{ karyotype abnormalities } \\
\hline & & & $\begin{array}{c}\text { absolute numbers, } \\
\mathrm{n}\end{array}$ & frequency, $\%$ & $\begin{array}{l}\text { absolute } \\
\text { numbers, } \mathrm{n}\end{array}$ & frequency, $\%$ \\
\hline
\end{tabular}


6.83), and carrying $D Q A 1 * 0501$ allele increases the $\mathrm{RPL}$ risk in women by two times $(\mathrm{OR}=2.2$; CI-95\%: 1.06 - 4.59). The results of positive association of given alleles with RPL are concordant with other publications [33] and support our colleagues observations [33-38] that the presence of specific allelic variants of genes $D R$ and $D Q$, that belong to HLA loci, in the mother can create the environment where the mother immune system does not recognize the fetus antigens and does not involve the mechanisms aimed at the protection of the fetus.

The results were also analyzed from the perspective of similarity of allelic variants of genes $H L A$ $D R B 1$ and HLA-DQAI between the partners. Homology between the partners is considered to be critical if the allelic polymorphism homology is more than $50 \%$ (when the partners have at least one similar allele of each locus). We have observed an increased frequency of homology of studied genes between partners in couples with RPL $-42.10 \%$ versus $17.65 \%$ in control group (Table 4).

Odds ratio calculation showed a four-time increase of the RPL risk in the couples with the interpartner allelic variant homologies of genes $H L A$ $D R B 1$ and HLA-DQA1 (OR $=3.60$; CI $-95 \%: 1.22-$ 10.68).

We have analyzed the results of the cytogenetic investigations of the RPL material in light of the inter-partner homology of the investigated HLA loci. In 36 couples we have cytogenetically investigated the samples from one SA, in two couples - from two SA. There were no significant differences in frequency and spectrum of chromosomal anomalies dependent on the level of inter-partner HLA homology (Table 5).

\section{Conclusions}

1. Cytogenetic and molecular-cytogenetic investigations of SA material identified karyotype anomalies in $32.4 \%$ of cases with prevalence of autosomal trisomy $-42.65 \%$, triploidy $-30.38 \%$ and monosomy $X-19.11 \%$. Among the miscarriages the sex ratio $\mathrm{XY}: \mathrm{XX}$ was 1.2 .

2. Complex analysis of frequency and distribution of allelic variants of genes $H L A-D R B 1$ and $H L A-D Q A 1$ permitted to establish the alleles $D R B 1 * 0301$, $D R B 1^{*} 1101-1104$ and $D Q A 1 * 0501$ to be aggressor ones in the women with RPL. The female carriers of the $D Q A 1 * 0501$ allele have a twice higher RPL risk $(\mathrm{OR}=2.2$; CI $-95 \%$ : 1.06-4.59).

3 . The cumulative homology of allelic polymorphism of more than $50 \%$ of the HLA-DRB1 and $H L A-D Q A 1$ loci between the partners increases the RPL risk of by almost four times $(\mathrm{OR}=3.60$; $\mathrm{CI}-$ $95 \%: 1.22-10.68$ ).

4. No differences in the frequency of chromosomal anomalies were found in the material of spontaneous abortions in couples with different level of homology of the HLA-DRB1 and HLA-DQA1 loci.

\section{Acknowledgements}

We sincerely wish to thank all the team members of the «Institute of Human Genetics, Jena, Germany» for the assistance in the conduction of this research.

\section{Funding}

This work was partially supported by the West-Ukrainian BioMedical Research Center grant (17-th Annual competition WUBMRC (2013-2014)).

\section{REFERENCES}

1. Katz VL. Spontaneous and recurrent abortion: etiology, diagnosis, treatment. In: Comprehensive Gynecology. Eds Lentz GM, Lobo RA, Gershenson DM. 6th ed. Philadelphia, PA: Elsevier Mosby; 2012; chap 16.

2. Mohangoo AD, Blondel B, Gissler $M$, et al. International comparisons of fetal and neonatal mortality rates in highincome countries: should exclusion thresholds be based on birth weight or gestational age? PLoS One. 2013;8(5): e64869.

3. Rai R, Regan L. Recurrent miscarriage. Lancet. 2006;368 (9535):601-11. Review.

4. Stirrat GM. Recurrent miscarriage. Lancet. 1990;336 (8716): 673-5.

5. Farcas S, Belebgeanu V, Popa $C$, et al. Role of chromosomal translocations in recurrent spontaneous abortion. Timisoara Medical Journal. 2007; 57(2-3):117-21.

6. Balakhonov $A V$. Mistakes in development. Leningrad: Ed. Lenengrad Univ. 1990. 278 p.

7. Yudina EV Trisomy 18: an analysis of 28 cases of prenatal diagnosis. Prenatalnaya Diagnostika. 2002; 1(1): 35-42. 
8. Delhanty JD, Handyside AH. The origin of genetic defects in the human and their detection in the preimplantation embryo. Hum Reprod Update. 1995;1(3):201-15.

9. Goddijn M, Leschot NJ. Genetic aspects of miscarriage. Baillieres Best Pract Res Clin Obstet Gynaecol. 2000;14(5): 855-65.

10. Baranov V.S., Kuznetsova TV. Cytogenetics of human embryonic development. St-Pb.: N-L. 2007; 170-209.

11. Kim JW, Lee WS, Yoon TK, et al. Chromosomal abnormalities in spontaneous abortion after assisted reproductive treatment. BMC Med Genet. 2010;11:153.

12. Franssen MT, Musters AM, van der Veen F, et al. Reproductive outcome after PGD in couples with recurrent miscarriage carrying a structural chromosome abnormality: a systematic review. Hum Reprod Update. 2011;17(4): 467-75.

13. Shearer BM, Thorland EC, Carlson AW, Jalal SM, Ketterling $R P$. Reflex fluorescent in situ hybridization testing for unsuccessful product of conception cultures: a retrospective analysis of 5555 samples attempted by conventional cytogenetics and fluorescent in situ hybridization. Genet Med. 2011;13(6):545-52.

14. Yurov YB, Vorsanova SG, Soloviev IV. et al. Original collection of DNA probes for preimplantational, fetal prenatal and postnatal diagnosis of chromosomal analysis by FISH. In: Early prenatal diagnosis, fetal cells and DNA in mother. Present state and perspectives. Eds. Macek M, Bianchi D, Cuckle H. Prague: The Carolinum Press. 2002; 275-83.

15. Tavokina LV, Brovko AA, Sopko IaA, Baronova EV. Karyotyping results of spontaneous abortions and miscarriages specimens obtained after using assisted reproductive technologies. Tsitol Genet. 2013;47(1):74-9.

16. Tavokina LV, Sopko NI, Khazhilenko KG, Baronova EV. Molecular-cytogenetic study of the aborted fetuses in women with reproductive function disorders. Tsitol Genet. 2006; 40(2):72-8.

17. Diego-Alvarez D, Ramos-Corrales C, Garcia-Hoyos M, et al. Double trisomy in spontaneous miscarriages: cytogenetic and molecular approach. Hum Reprod. 2006;21(4): 958-66.

18. Vorsanova SG, Iourov IY, Kolotii AD, et al. Chromosomal mosaicism in spontaneous abortions: Analysis of 650 cases. Russian Journal of Genetics. 2010;46(10):1197-200.

19. Gardner RJM, Sutherland GR, Shaffer LG. Chromosome abnormalities and genetic counselling. Oxford University Press. 2011; 61. $4^{\text {th }}$ ed.

20. Pflueger SM. Cytogenetics of spontaneous abortions. In: The principles of cytogenetics. Eds Gersen SI, Keagle MB. Humana Press. Totowa. New Jersey. USA. 2005; 323-45.

21. Jobanputra V, Sobrino A, Kinney A, Kline J, Warburton D. Multiplex interphase FISH as a screen for common aneuploidies in spontaneous abortions. Hum Reprod. 2002;17 (5):1166-70.

22. Yurov YB, Soloviev IV, Vorsanova SG, Marcais B, Roizes $G$, Lewis $R$. High resolution multicolor fluorescence in situ hybridization using cyanine and fluorescein dyes: rapid chro- mosome identification by directly fluorescently labled alphoid DNA probes. Hum Genet. 1996;97(3):390-8.

23. Bielanska M, Tan SL, Ao A. Chromosomal mosaicism throughout human preimplantation development in vitro: incidence, type, and relevance to embryo outcome. Hum Reprod. 2002;17(2):413-9.

24. Aruna M, Nagaraja T, Andal Bhaskar $S$, et al. Novel alleles of HLA-DQ and -DR loci show association with recurrent miscarriages among South Indian women. Hum Reprod. 2011;26(4):765-74.

25. Sipak-Szmigiel O, Ronin-Walknowska E, Mikłaszewicz A, Dotubeczko A, Zejmo M, Giedrys-Kalemba S. Association between HLA-DQA1, HLA-DQB1 alleles and risk of early pregnancy loss. Ginekol Pol. 2007;78(10):792-5.

26. Takakuwa K, Adachi H, Hataya I, Ishii K, Tamura M, Tanaka $K$. Molecular genetic studies of HLA-DRB1 alleles in patients with unexplained recurrent abortion in the Japanese population. Hum Reprod. 2003;18(4):728-33.

27. Beydoun H, Saftlas AF. Association of human leucocyte antigen sharing with recurrent spontaneous abortions. Tissue Antigens. 2005;65(2):123-35.

28. Varla-Leftherioti M, Keramitsoglou T, Spyropoulou-Vlachou $M$, et al. $14^{\text {th }}$ International HLA and Immunogenetics Workshop: report from the reproductive immunology component. Tissue Antigens. 2007;69 Suppl 1:297-303.

29. Baranov VS. A method of shaking-blotting--a simple and reliable means for obtaining direct chromosomal preparations from chorionic biopsies. Tsitologiia. 1989;31(2): 251-3.

30. Liehr T, Pellestor F. Molecular cytogenetics: the standard FISH and PRINS procedure. In: Fluorescence in situ hybridization (FISH) - application guide Ed. Liehr T. Springer-Verlag, Berlin Heidelberg. 2009; 23-34.

31. Moghraby JS, Tamim H, Anacan V, Al Khalaf H, Moghraby $S A$. HLA sharing among couples appears unrelated to idiopathic recurrent fetal loss in Saudi Arabia. Hum Reprod. 2010;25(8):1900-5.

32. Terpylyak OI, Sosnina KO, Zastavna DV, Helner NV, Mikula $M I$. The distribution of allelic variants of genes $H L A-D R B 1$, $H L A-D Q A 1, H L A-D Q B 1$ and HLA-G among women with idiopathic recurrent pregnancy loss. Biopolym Cell. 2013; 29(5):413-7.

33. Kruse C, Steffensen R, Varming K, Christiansen OB. A study of HLA-DR and -DQ alleles in 588 patients and 562 controls confirms that HLA-DRB $1 * 03$ is associated with recurrent miscarriage. Hum Reprod. 2004;19(5):1215-21.

34. Takakuwa K, Honda K, Yokoo T, Hataya I, Tamura M, Tana$k a K$. Molecular genetic studies on the compatibility of HLA class II alleles in patients with unexplained recurrent miscarriage in the Japanese population. Clin Immunol. 2006; 118(1):101-7.

35. Shankarkumar U, Pawar A, Gaonkar P, Parasannavar D, Salvi $V$, Ghosh K. HLA allele associations in idiopathic recurrent spontaneous abortion patients from India. J Hum Reprod Sci. 2008;1(1):19-24. 
Contribution of chromosomal abnormalities and genes of the major histocompatibility complex to early pregnancy losses

36. Steck T, van der Ven K, KwakJ, Beer A, Ober C. HLA-DQA1 and HLA-DQB1 haplotypes in aborted fetuses and couples with recurrent spontaneous abortion. J Reprod Immunol. 1995;29(2):95-104.

37. Wang XP, Lin $Q D, L u P H, M a Z W$, Zhao AM. Association of HLA-DQB1 coding region with unexplained recurrent spontaneous abortion. Chin Med J (Engl). 2004;117(4): 492-7.

38. Lin $Q$, Lu P, Wang $X$. The study on human leucocyte antigen DQ region genes polymorphism in unexplained habitual abortion patients. Zhonghua Fu Chan Ke Za Zhi. 2001;36(5): 293-5.

І. Р. Ткач, К. О. Сосніна, Н. Л. Гулеюк, О. І. Терпиляк, Д. В. Заставна, А. Вайсе, Н. Косякова, Т. Лір

Внесок хромосомних порушень та генів головного комплексу гістосумісності в генез ранніх репродуктивних втрат

Мета: встановити хромосомні аномалії у матеріалі ранніх репродуктивних втрат і алельний поліморфізм генів HLA $D R B 1$ i $D Q A 1$ у подружніх пар із навиковим невиношуванням вагітності. Методи: стандартний цитогенетичний та інтерфазний mFISH методи, виділення ДНК методом висолювання, ПЛР, електрофорез в агарозному гелі. Результати: В результаті проведених цитогенетичних та молекулярно-цитогенетичних досліджень матеріалу втрачених вагітностей аномалії каріотипу встановлено в 32.4 \% випадках з переважанням аутосомних трисомій $-42.65 \%$, триплоїдій $-30.38 \%$ i моносомії $\mathrm{X}-19.11 \%$. Комплексний аналіз частоти і розподілу алельних варіантів генів HLA-DRB1 і HLA-DQA1 дозволив встановити, що $D R B 1 * 0301, D R B 1 * 1101-1104$ і $D Q A 1 * 0501 \epsilon$ алелями-агресорами у жінок із ранніми репродуктивними втратами (РРВ). Сукупна гомологія алельного поліморфізму локусів HLA-DRB1 і HLA-DQA1 більше 50 \% між партнерами збільшує ризик РРВ майже в чотири рази. Висновки: встановлені хромосомні анеуплоїдії в матеріалі втрачених вагітностей та зміни в генах головного комплекса гістосумістності у подружніх пар можуть викликати порушення репродуктивної функції та ранню елімінацію плода.
Кл юч о в і с л о в а: невиношування вагітності, хромосомні аномалії, цитогенетика, хромосоми, FISH, HLA-генотипування.

И. Р. Ткач, К. А. Соснина, Н. Л. Гулеюк,

О. И. Терпиляк, Д. В. Заставна, А. Вайсе,

Н. Косякова, Т. Лир

\section{Вклад хромосомных нарушений и генов главного комплекса гистосовместимости в генез ранних репродуктивных потерь}

Цель. Изучить хромосомные аномалии в биологическом материале ранних репродуктивных потерь и аллельный полиморфизм генов $H L A-D R B 1$ u $D Q A 1$ у супружеских пар с привычным невынашиванием беременности. Методы: стандартный цитогенетический и интерфазный mFISH методы, выделение ДНК методом высаливания, ПЦР, электрофорез в агарозном геле. Результаты. Проведенные цитогенетические и молекулярно-цитогенетические исследования материала ранних репродуктивных потерь показали аномалии кариотипа в $32.4 \%$ случаев с преобладанием аутосомных трисомий $-42.65 \%$, триплоидий $-30.38 \%$ и моносомии X $-19.11 \%$. Комплексный анализ частоты и распределения аллельных вариантов генов HLA-DRB1 и HLA-DQA1показал, что $D R B 1 * 0301, D R B 1 * 1101-1104$ и $D Q A 1 * 0501$ являются аллелями-агрессорами у женщин с ранними репродуктивными потерями (РРП). Совокупная гомология аллельного полиморфизма локусов $H L A-D R B 1$ и HLA-DQA1 более $50 \%$ между партнерами увеличивает риск РРП почти в четыре раза. Выводы: Выявленные хромосомные анеуплоидии в материале самопроизвольных выкидышей и изменения в генах главного комплекса гистосовместимости у супружеских пар могут вызывать нарушения репродуктивной функции и элиминацию плода в раннем периоде беременности.

Ключевы е слова: невынашивание беременности, хромосомные аномалии, цитогенетика, хромосомы, FISH, HLAгенотипирование.

Received 25.12.2014 